\title{
Nutraceutical Properties of Meat from Grazing Podolian Young Bulls
}

\author{
Rosaria Marino*, Marzia Albenzio, Antonella della Malva, Ada Braghieri, Agostino Sevi \\ Department of the Sciences of Agriculture, Food and Environment, \\ University of Foggia, Foggia, Italy \\ Email: ${ }^{*}$ rosaria.marino@unifg.it
}

Received 20 December 2013; revised 20 January 2014; accepted 27 January 2014

Copyright $@ 2014$ by authors and Scientific Research Publishing Inc.

This work is licensed under the Creative Commons Attribution International License (CC BY). http://creativecommons.org/licenses/by/4.0/

(c) (i) Open Access

\section{Abstract}

The effect of rearing system (pasture with supplementation 15\% crude protein OUT15 vs indoor IND) on meat nutritional and nutraceutical properties was evaluated in twenty Podolian young bulls. Meat quality characteristics were measured on three different muscles (Longissimus dorsi, LD, Semimembranosus, SM, Semitendinosus, ST), vacuum-packaged and chilled stored at $2^{\circ} \mathrm{C}-4^{\circ} \mathrm{C}$ for 15 days. No differences were found on chemical composition in meat from animals reared with different rearing system. Pasture with supplementation produced an improvement in fatty acid composition with a higher polyunsaturated fatty acid percentage, particularly, conjugated linoleic acids (CLA) and very long chain $\omega 3$ PUFA, such as eicosapentaenoic acid (EPA) and docosahexaenoic acid (DHA). Meat from young bulls reared at pasture with supplementation showed in all examined muscles the highest $\alpha$-tocopherol content compared with meat from IND group. On the other hand, malondialdehyde content was not affected by the feeding treatment.

\section{Keywords}

Podolian Cattle; Fatty Acid; PUFA; Nutraceutical Properties; EPA; DHA

\section{Introduction}

Nutritional properties of meat and meat products are becoming very important in purchasing behaviour because consumers are even more concerned about healthiness (e.g. fat and protein content, fatty acids composition, etc.) and their choices could depend on how they are informed of the attributes of products [1]. Nutritionists recommend not only limiting fat intake but also consuming large amounts of polyunsaturated fatty acids (PUFA), especially $\omega 3$ PUFA rather than $\omega 6$ PUFA [2].

\footnotetext{
${ }^{*}$ Corresponding author.
} 
Previous studies [3] [4] confirm that meat nutritional composition can be influenced by several factors such as diet, breed, age/weight and fatness. Feeding strategy can play an important role in increasing meat nutritional quality. In particular, pasture feeding has been found to increase the concentration of polyunsaturated fatty acids in beef, especially $\omega 3$ PUFA, compared with grain feeding [5]. Even if, in ruminants, feeding strategy is considered to be more difficult to influence the fatty acid composition of the meat, compared with monogastric animals, due to rumen hydrogenation. Therefore, rearing system can be used to manipulate the fatty acid content of muscle in an attempt to improve nutritional balance.

Extensive rearing systems of farm animals are perceived by consumers as strongly linked to healthfulness, animal welfare, sustainability, and safety, so these systems are highly desirable, and for this reason, the market demand is greater. In addition, this rearing technique ensures high ecosystem sustainability, improving the role of agriculture in environment preservation. In terms of human-edible returns, increased sustainability was found from Podolian cattle and their farming system [6]. Similar to Chianina, Romagnola, Marchigiana, and Maremmana cattle, Podolian cattle are an important breed of cattle in Italy. Recent sources reported a total of 24,265 Podolian cattle [7], which is an increase in the number of animals after a reduction in numbers in the last several years. These cattle are a rustic breed reared in southern Italy and adapted to the difficulty of the surrounding environment, such as the poor quality forages available in southern Italian pastures [8]. Although these animals exploit pasture, the use of protein supplementation is necessary to increase cattle body weight due to low summer rainfall and poor pasture quality in most areas of southern Italy ( $<6 \% \mathrm{CP}$, dry matter basis). Therefore, it could be useful assessing both genetic growth potential of the Podolian breed, which is still unexplored, and its meat nutritional properties through administration of a relatively high protein level diet or using a different rearing system.

In particular, the objective of the present study was to investigate the nutritional properties and nutraceutical traits of meat in Podolian young bulls.

\section{Materials and Methods}

\subsection{Experimental Design and Animal Management}

The experiment, which lasted 172 days, was conducted from June to November in the Gargano National Park, $60 \mathrm{~km}$ northwest of Foggia, Southern Italy, with an elevation of about $300 \mathrm{~m}$ above sea level. The climate of this area is Mediterranean, with about $500 \mathrm{~mm}$ of annual rainfall, mainly distributed in late autumn and winter, and a $22.1^{\circ} \mathrm{C}$ mean maximum temperature (often over $30^{\circ} \mathrm{C}$ in summer). The experiment involved 20 young Podolian bulls that averaged $415 \pm 9.35$ (SE) days of age, with a mean body weight of $337.5 \pm 16.51$ (SE) kg. The animals were allotted for the finishing period (172 days) to 2 groups of 10 subjects, according to rearing system: 1 ) indoor group receiving a diet with $15 \%$ protein level-IND, 2) grazing animals receiving a supplementation with $15 \%$ crude protein of dry matter-OUT15. Animals of OUT15 group had free access to a pasture (14.5 ha) and were fed at 18:00 h returning from pasture. Hay and concentrate were simultaneously administrated in cribs and mangers; feeder space per animal was about $0.6 \mathrm{~m}$. Diet was composed of oats hay as forage plus durum wheat flour shorts and field beans as concentrates and was calculated according to INRA [9] to satisfy the growth requirement. Water was available ad libitum for all the experimental groups. Before the beginning of the trial, all the animals were treated against gastrointestinal parasites by application of Ivermectin (Valbazen, Pfizer, Genval, Belgium). The composition of the grass was typical of summer grass with high DM. The botanical composition of the sward consisted predominantly of Graminaceae [orchard grass (Dactylis glomerata L.), smooth barley (Hordeum murinum), sterile oats (Avena sterilis)], and to a smaller extent of Leguminosae [alfalfa (Medicago sativa L.), chickling vetch (Lathyrus articulatus L.), sainfoin (Onobrychis saxatilis L.)] and Compositae. These botanical families and species were always distributed in complex mixtures.

Animals were slaughtered at 19 mo of age after reaching a mean slaughter weight of $510 \pm 13.8$ (SE) kg, according to industrial routines used in Italy and European Union rule number 119/1993. One hour after slaughter, the dressed carcasses were weighed, split into 2 halves, and chilled for $48 \mathrm{~h}$ at $1^{\circ} \mathrm{C}$ to $3^{\circ} \mathrm{C}$. The right half was divided in hind- and forequarters, and each quarter was dissected into different anatomical regions. Longissimus dorsi (LD), Semitendinosus (ST) and Semimembranosus (SM) muscles were removed and aged in vacuum packaging at $2^{\circ} \mathrm{C}$ until 15 days postmortem. 


\subsection{Nutritional Analysis}

Each sample was ground to homogeneous consistency using a food processor. Moisture, protein, fat and ash contents in each sample were determined according to AOAC methods [10]. All the chemical determinations were performed in duplicate.

Lipids were extracted according to the method used by Folch et al. [11]. Briefly, a $5 \mathrm{~g}$ homogenised meat sample was blended with chloroform/methanol (2:1, v/v) twice for $60 \mathrm{~s}$, filtered, placed in separator funnels and mixed with saline solution $(0.88 \% \mathrm{KCl})$. After separation in two phases, the methanol aqueous fraction was discarded, whereas the lipid chloroform fraction was washed with distilled water/methanol (1:1, v/v). After a further filtration and evaporation by means of a rotary evaporator, lipid extracts were transferred to test tubes for subsequent gas chromatographic analysis. Duplicate samples of chloroform extract, corresponding to $100 \mathrm{mg}$ of lipid, were methylated by adding $1 \mathrm{ml}$ of hexane and $0.05 \mathrm{ml}$ of $2 \mathrm{~N}$ methanolic $\mathrm{KOH}$ according to ISO-IDF. Gas-chromatograph analysis was performed using an Agilent 6890N instrument equipped with a HP-88 fusedsilica capillary column (length $100 \mathrm{~m}$, internal diameter $0.25 \mathrm{~mm}$, film thickness $0.25 \mu \mathrm{m}$ ). Operating conditions were: a helium flow rate of $0.7 \mathrm{ml} / \mathrm{min}$; a FID detector at $260^{\circ} \mathrm{C}$; a split-splitless injector at $220^{\circ} \mathrm{C}$ with an injection rate of $120 \mathrm{ml} / \mathrm{min}$ and an injection volume of $1: 1$. The temperature programme of the column was: 4 min at $140^{\circ} \mathrm{C}$ and a subsequent increase to $220^{\circ} \mathrm{C}$ at $4^{\circ} \mathrm{C} / \mathrm{min}$. Retention time and area of each peak were computed using the 6890N NETWORK GC system software. Individual fatty acids methyl ester (FAME) peaks were identified by comparing their retention times with those of standards (Supelco 37 component FAME mix; conjugated methyl ester). Results are expressed as percentage of total fatty acids analysed and the mean value of each fatty acid was used to calculate total saturated (SFA), monounsaturated (MUFA) and polyunsaturated (PUFA) fatty acids. Atherogenic and thrombogenic indices were calculated according to Ulbricht and Southgate [12] as follow:

$$
\text { atherogenic index }=(\mathrm{C} 12: 0+4 \times \mathrm{C} 14: 0+\mathrm{C} 16: 0) /\left[\left(\sum \operatorname{MUFA}+\sum \operatorname{PUFA}(\omega-6) \text { and }(\omega-3)\right)\right] ;
$$

thrombogenic index

$$
=(\mathrm{C} 14: 0+\mathrm{C} 16: 0+\mathrm{C} 18: 0) /\left[\left(0.5 \times \sum \operatorname{MUFA}+0.5 \times \sum \operatorname{PUFA}(\omega-6)+3 \times \sum \operatorname{PUFA}(\omega-3)+(\omega-3) /(\omega-6)\right)\right] \text {. }
$$

\subsection{Determination of $\alpha$-Tocopherol from Muscular Tissue and of Oxidative Stability}

$\alpha$-tocopherol was extracted from each meat sample following the method of Piironen et al. [13]. $1 \mathrm{~g}$ sample was homogenized, $2 \mathrm{ml}$ of an ethanolic butylated hydroxytolene (BHT) solution $(0.1 \% \mathrm{w} / \mathrm{v})$ were added and vortex mixed. Subsequently, $2.8 \mathrm{ml}$ of ascorbic solution $(8.8 \% \mathrm{w} / \mathrm{v})$ and $2.5 \mathrm{ml}$ of $\mathrm{KOH}$ were added. Tubes were then placed in a test tube rack and incubated in a shaking water bath $\left(80^{\circ} \mathrm{C}\right.$ for $\left.15 \mathrm{~min}\right)$. After the incubation, test tubes were cooled in ice and $4 \mathrm{ml}$ of hexane HPLC and the internal standard 5,7-Dimethyltocol (DMT) were added and then mixed. Samples were centrifuged for $5 \mathrm{~min}$ for phase separation, the upper phase was transferred into clean tube and evaporated to dryness at $60^{\circ} \mathrm{C}$. Dried residue was reconstituted immediately with $1 \mathrm{ml}$ hexane and transferred into a $2 \mathrm{ml}$ amber glass vial. Vitamin E levels in the extract were measured by HPLC. Samples $(20 \mu \mathrm{l})$ were injected into a Lichosorb Si column with $98 \%$ hexane mixed with $2 \%$ 2-propanol as mobile phase, at a flow rate of $1.6 \mathrm{ml} / \mathrm{min}$. $\alpha$-tocopherol concentrations ( $\mu \mathrm{g} \alpha$-tocopherol/g muscle) were determined with a fluorescence detector from peak height with comparisons to known amount of internal standard.

Lipid oxidation was determined by measuring the reaction of malondialdehyde (MDA) with 2-thiobarbituric acid (TBA) [14] and expressed as mg MDA/kg meat.

\subsection{Statistical Analysis}

All data were subjected to analysis of variance, using the GLM procedure of the SAS statistical software [15].

The mathematical model included fixed effect due to rearing system, muscle and their interactions. When significant differences were found (at $\mathrm{P}<0.05$ unless otherwise noted), the Student $t$-test was used to locate significant differences between means. Least Squares means were evaluated using the PDIFF and STDERR options of SAS.

\section{Results and Discussion}

Rearing system did not affect meat chemical composition as shown in Table 1 . This result is in agreement with 
Table 1. Meat chemical composition (\%) of Podolian young bulls as affected by rearing system (OUT15 = outdoor with $15 \%$ of supplementation, IND = indoor; means $\pm \mathrm{SE}$ ).

\begin{tabular}{|c|c|c|c|c|c|c|c|}
\hline \multicolumn{5}{|c|}{ Rearing system } & \multicolumn{3}{|c|}{ Effects, $P$} \\
\hline & & OUT15 & IND & SE & Rearing system & muscle & Rearing system $\times$ muscle \\
\hline \multirow{3}{*}{ Moisture } & ST & 74.80 & 74.65 & 0.38 & \multirow{3}{*}{ NS } & \multirow{3}{*}{ NS } & \multirow{3}{*}{ NS } \\
\hline & SM & 75.07 & 74.80 & 0.40 & & & \\
\hline & LD & 74.45 & 74.48 & 0.41 & & & \\
\hline \multirow{3}{*}{ Protein } & ST & 23.25 & 22.85 & 0.30 & & \multirow{3}{*}{$* * *$} & \multirow{3}{*}{ NS } \\
\hline & SM & 22.85 & 22.05 & 0.28 & NS & & \\
\hline & LD & 23.20 & 23.25 & 0.31 & & & \\
\hline \multirow{3}{*}{ Fat } & ST & 1.18 & 1.25 & 0.21 & & \multirow{3}{*}{$* *$} & \multirow{3}{*}{ NS } \\
\hline & SM & 1.48 & 1.55 & 0.20 & NS & & \\
\hline & LD & 1.75 & 1.70 & 0.19 & & & \\
\hline \multirow{3}{*}{ Ash } & ST & 1.13 & 1.13 & 0.05 & \multirow{3}{*}{ NS } & \multirow{3}{*}{ NS } & \multirow{3}{*}{ NS } \\
\hline & SM & 1.11 & 1.09 & 0.04 & & & \\
\hline & LD & 1.06 & 1.08 & 0.05 & & & \\
\hline
\end{tabular}

NS = not significant; ${ }^{* *} \mathrm{P}<0.01 ;{ }^{* * *} \mathrm{P}<0.001$.

a previous study [16] that found no effect of high energy diets on meat chemical composition. Significant differences emerged among muscles for protein, ash and fat contents. In particular, the protein content was higher in Semitendinosus and Longissimus dorsi than in Semimembranosus $(\mathrm{P}<0.001)$, while Longissimus dorsi had the highest and Semitendinosus the lowest fat content $(\mathrm{P}<0.01)$. Meat from Podolian young bulls showed mean fat and protein values of $1.48 \%$ and $22.91 \%$, respectively, while, moisture content was $74.71 \%$. The fat content values found in our study indicate a lean meat, according to the Food Advisory Committee [17] which reported that meat containing less than $5 \%$ total lipid could be regarded as lean. The low fat content of Podolian meat is an important result from nutritional point of view. Lipids are among the bioactive components those that have received most attention, in quantitative and qualitative terms, with respect to the development of healthier meat and meat products.

Pasture with supplementation caused a significant increase in unsaturation level of intramuscular fat (Table 2). OUT15 group showed lower percentage of saturated (SFA, P $<0.01$ ) and higher percentages of monounsaturated (MUFA, $\mathrm{P}<0.001$ ) and polyunsaturated (PUFA, $\mathrm{P}<0.001$ ) fatty acids compared to the IND group. Although SFA are believed to present the greatest risk factor because of their hyper cholesterolaemic effect, they do not all act in the same way [18]. Meat from young bulls reared at pasture showed a remarkable result from nutritional point of view with the lowest content of myristic and palmitic acids that account for approximately $22 \%$ of total fatty acids compared with about $27 \%$ in meat from young bulls reared indoor. Among saturated fatty acids, the greater atherogenic effect is produced by palmitic and especially myristic acids, while, stearic acid appears to have no effect on cholesterol levels [19].

Polyunsaturated fatty acids are considered protective factors being involved in the reduction of risk of human coronary heart disease [20]. In particular, the proportion of linoleic acid (C18:2 $\omega-6)$, linolenic acid (C18:3 $\omega-3)$, eicosapentaenoic acid (EPA-C20:5 $\omega$-3), docosapentaenoic acid (DPA-C22:5 $\omega$-3) and docosahexaenoic acid (DHA-C22:6 $\omega$-3) were significantly higher in the OUT15 group. These results are in agreement with Yang et al. [5] who found a higher concentration of $\omega$-3 PUFA in body tissues of animals receiving forage or grass-based diets. The increase in the proportion of EPA, DPA and DHA in grazing animals suggests that the high availability of C18:3 $\omega$-3 in grass has resulted in an enhanced synthesis of these long chain fatty acids. In ruminants, the essential fatty acid C18:3 $\omega$-3 can be converted to longer and more unsaturated $\omega$-3 PUFA, such as EPA and DHA [21].

The highest percentage of EPA and DHA in meat of young bulls fed reared at pasture with supplementation are indicative of a nutraceutical properties of meat; among the $\omega$-3 PUFA, these fatty acids have been reported to have a wide range of biological effects, which are beneficial for human health. EPA and DHA have been demonstrated to have a role in prevention of heart diseases and some cancers and obesity/type-2 diabetes [2]. DHA is also important during pregnancy for cerebral and retinal tissues development and reduces the incidence 
Table 2. Meat fatty acid composition (\%) of Podolian young bulls as affected by different rearing system (IND = indoor, OUT15 = outdoor with $15 \%$ of supplementation; means \pm SE).

\begin{tabular}{|c|c|c|c|c|}
\hline \multicolumn{5}{|c|}{ Rearing System } \\
\hline & OUT15 & IND & SE & Effect, $P$ \\
\hline C 12:0 & 0.55 & 0.68 & 0.08 & NS \\
\hline C 14:0 & 1.33 & 2.05 & 0.11 & ${ }^{*}$ \\
\hline C 16:0 & 21.55 & 25.12 & 0.35 & $* * *$ \\
\hline C 17:0 & 2.51 & 2.69 & 0.11 & ${ }^{* *}$ \\
\hline C 18:0 & 16.82 & 17.55 & 0.22 & NS \\
\hline C $16: 1$ & 1.01 & 0.95 & 0.04 & NS \\
\hline C $18: 1$ & 37.25 & 34.85 & 0.52 & ${ }^{* *}$ \\
\hline C $18: 2 n-6$ & 10.25 & 9.25 & 0.31 & ${ }^{*}$ \\
\hline CLA & 0.78 & 0.23 & 0.10 & $* * *$ \\
\hline C $18: 3 n-3$ & 0.85 & 0.55 & 0.08 & ${ }^{*}$ \\
\hline C $20: 2 n-6$ & 0.65 & 0.56 & 0.10 & NS \\
\hline C 20:4 n-6 & 3.35 & 3.10 & 0.22 & NS \\
\hline C 20:5 n-3 EPA & 1.10 & 0.65 & 0.07 & $* *$ \\
\hline C 22:5 n-3 DPA & 1.85 & 1.22 & 0.10 & ${ }^{* * *}$ \\
\hline C 22:6 n-3 DHA & 0.28 & 0.11 & 0.03 & $* * *$ \\
\hline$\omega 3$ & 4.08 & 2.53 & 0.22 & $* * *$ \\
\hline$\omega 6$ & 15.03 & 13.14 & 0.41 & ${ }^{*}$ \\
\hline SFA & 42.76 & 48.09 & 0.64 & $* *$ \\
\hline MUFA & 38.26 & 35.80 & 0.51 & $* * *$ \\
\hline PUFA & 19.11 & 15.67 & 0.77 & $* * *$ \\
\hline
\end{tabular}

NS = not significant; ${ }^{*} \mathrm{P}<0.05 ;{ }^{* *} \mathrm{P}<0.01 ;{ }^{* * *} \mathrm{P}<0.001$.

of premature birth [22].

In addition meat from animals reared at pasture showed the highest content of CLA ( $0.78 \%$ vs $0.23 \%)$. There is clear evidence of an enhanced proportion of CLA in grass fed animals compared with concentrate fed animals, as shown by previous studies [16] [23]. CLA has considerable potential benefits in human diet. Cis-9, trans-11 and trans-10, cis-12 isomers have been associated with the inhibition of carcinogenesis, the reduction of atherosclerosis, modification of the immune response, the distribution of body fat and a reduction in body-fat deposits [24]. CLA also exhibits antioxidant properties, inhibiting the discolouration of meat during storage [25] [26].

Different rearing markedly affected nutritional indexes and fatty acid ratios of meat (Table 3). Meat from bulls reared at pasture showed a better nutritional profile with lower atherogenic $(\mathrm{P}<0.05)$ and thrombogenic $(\mathrm{P}$ $<0.05)$ indexes and $\Sigma \omega 6 / \Sigma \omega 3$ ratio $(\mathrm{P}<0.01)$ as well as a higher PUFA/SFA ratio $(\mathrm{P}<0.001)$ than IND group. $\omega-6 / \omega-3$ PUFA ratio, in meat from animals reared at pasture with supplementation, was beneficially low being 3.64, lower than value of 4 recommended by nutritionists [27]. Polyunsaturated to saturated ratio (PUFA/SFA) in ruminant meat is unfavourably low because dietary unsaturated fatty acids are hydrogenated by rumen micro-organisms [28], in this research, the P/S ratio fell within the recommend range $(0.3-0.6)$ being 0.45 and 0.33 in OUT15 and IND group, respectively. Although the PUFA/SFA and $\omega 6 / \omega 3$ ratios of meat are important factors from the human nutrition standpoint, specific saturated and polyunsaturated fatty acids have opposite metabolic effects. The estimate of atherogenic and thrombogenic indices quantifies the fatty acids that can promote or prevent atherosclerosis and coronary thrombosis.

Irrespective to rearing system, meat of Podolian young bulls showed higher content of PUFA than values reported by De la Fuente et al. [29] in Friesian and Limousin bulls and by Gatellier et al. [30] in Charolaise steers. It can be hypothesized that this breed produces a favourable content of PUFA as a possible consequence of its lean nature. Indeed, ruminants preferentially deposit PUFA in phospholipids so very lean breeds could have relatively high proportions of PUFA compared with fatter breeds [31].

The muscle affected fatty acid composition as shown in Table 4. LD muscle showed higher percentage of SFA ( $<<0.001)$, particularly, palmitic acid $(\mathrm{P}<0.01)$ and lower percentage of PUFA $(\mathrm{P}<0.01)$ ), particularly, 
Table 3. Nutritional indexes in meat of Podolian young bulls as affected by different rearing system (IND = indoor, OUT15 $=$ outdoor with $15 \%$ of supplementation; means $\pm \mathrm{SE}$ ).

\begin{tabular}{ccccc}
\hline & Rearing System & & \\
\hline & OUT15 & IND & SE & Effect, P \\
\hline$\Sigma \omega 6 / \Sigma \omega 3$ & 3.68 & 5.19 & 0.22 & $* *$ \\
$\mathrm{P} / \mathrm{S}$ & 0.45 & 0.33 & 0.02 & $* .03$ \\
$\mathrm{AI}$ & 0.48 & 0.66 & 0.10 & $*$ \\
$\mathrm{TI}^{2}$ & 1.01 & 1.39 & $*$ \\
\hline
\end{tabular}

NS = not significant; ${ }^{*} \mathrm{P}<0.05 ;{ }^{* *} \mathrm{P}<0.01 ;{ }^{* * *} \mathrm{P}<0.001 .{ }^{1}$ Atherogenic Index $=(\mathrm{C} 12: 0+4 \times \mathrm{C} 14: 0+\mathrm{C} 16: 0) /[(\mathrm{MUFA}+\mathrm{PUFA}(\omega-6)$ and $(\omega-3)]$; ${ }^{2}$ Thrombogenic Index $=($ C14:0 + C16:0 + C18:0 $) /[(0.5 \times$ MUFA $+0.5 \times$ PUFA $(\omega-6)+3 \times$ PUFA $(\omega-3)+(\omega-3) /(\omega 6)]$.

Table 4. Meat fatty acid composition (\%) of Podolian young bulls as affected by different muscles (means \pm SE).

\begin{tabular}{|c|c|c|c|c|c|c|c|c|}
\hline \multicolumn{9}{|c|}{ Muscles } \\
\hline & LD & & SM & & ST & & SE & Effect, $P$ \\
\hline C12:0 & 0.55 & & 0.68 & & 0.62 & & 0.10 & NS \\
\hline C14:0 & 1.78 & & 1.61 & & 1.65 & & 0.09 & NS \\
\hline C16:0 & 24.45 & $\mathrm{a}$ & 22.85 & $\mathrm{~b}$ & 22.67 & $\mathrm{~b}$ & 0.35 & ${ }^{* *}$ \\
\hline $\mathrm{C} 17: 0$ & 2.65 & & 2.55 & & 2.58 & & 0.11 & NS \\
\hline C18:0 & 17.35 & & 17.05 & & 17.16 & & 0.33 & NS \\
\hline C16:1 & 1.04 & & 0.92 & & 0.95 & & 0.05 & NS \\
\hline C $18: 1$ & 36.68 & & 35.77 & & 35.62 & & 0.54 & NS \\
\hline $\mathrm{C} 18: 2 \omega-6$ & 8.91 & $\mathrm{~b}$ & 10.25 & $\mathrm{a}$ & 10.13 & a & 0.35 & $*$ \\
\hline CLA & 0.48 & & 0.50 & & 0.53 & & 0.11 & NS \\
\hline $\mathrm{C} 18: 3 \omega-3$ & 0.52 & & 0.82 & & 0.78 & & 0.12 & NS \\
\hline $\mathrm{C} 20: 2 \omega-6$ & 0.55 & & 0.68 & & 0.63 & & 0.08 & NS \\
\hline $\mathrm{C} 20: 4 \omega-6$ & 3.18 & & 3.22 & & 3.35 & & 0.15 & NS \\
\hline C20:5 $\omega-3$ EPA & 0.76 & & 0.98 & & 0.85 & & 0.08 & NS \\
\hline C22:5 $\omega-3$ DPA & 1.44 & & 1.61 & & 1.55 & & 0.12 & NS \\
\hline C22:6 $\omega-3$ DHA & 0.19 & & 0.23 & & 0.26 & & 0.04 & NS \\
\hline SFA & 46.78 & $\mathrm{a}$ & 44.74 & $\mathrm{~b}$ & 44.68 & $\mathrm{~b}$ & 0.61 & * \\
\hline MUFA & 37.72 & & 36.69 & & 36.57 & & 0.79 & NS \\
\hline PUFA & 16.03 & $\mathrm{~b}$ & 18.29 & $\mathrm{a}$ & 18.08 & a & 0.56 & $* *$ \\
\hline
\end{tabular}

NS = not significant; ${ }^{*} \mathrm{P}<0.05 ;{ }^{* *} \mathrm{P}<0.01 ;{ }^{* * *} \mathrm{P}<0.001$.

linoleic acid $(\mathrm{P}<0.01)$ compared to SM and ST muscles. These results may be attributed to differences in phospholipids concentration and/or enzyme activities, which is greater in red oxidative muscle fibre compared to glycolytic muscles. Therefore, the relatively white LD is generally lower in PUFA percentage than SM in agreement with Enser et al. [31].

Significant diet effects were observed on meat $\alpha$-tocopherol content (Table 5). Meat from young bulls reared at pasture with supplementation showed in all examined muscles the highest $\alpha$-tocopherol content compared with meat from IND group. Our result are in agreement with previous studies [32] [33] that observed an increase of $\alpha$-tocopherol in the meat from animals reared at pasture with supplementation. High concentrations of vitamin E in muscle have been shown to increase the oxidative stability of beef [34], since vitamin E reduces lipid oxidation, improving meat quality characteristics such as colour, flavour, texture and nutritional value, as well as increasing shelf-life [35].

The reaction of MDA with TBA is widely used for measuring the extent of oxidative deterioration of lipid in muscle foods [36]. In the present trial, as shown in Table 5 lipid oxidation of meat was not affected by dietary treatments or muscle. 
Table 5. $\alpha$ tocopherol (mg/g) and MDA (mg/kg) content in meat of Podolian young bulls as affected by different rearing system (OUT15 = outdoor with $15 \%$ of supplementation, IND = indoor; mean \pm SE).

\begin{tabular}{|c|c|c|c|c|c|c|c|}
\hline & & \multirow[b]{2}{*}{ OUT15 } & \multirow[b]{2}{*}{ IND } & \multirow[b]{2}{*}{$\mathrm{SE}$} & \multicolumn{3}{|c|}{ Effects, $P$} \\
\hline & & & & & Rearing system & Muscle & Rearing system $\times$ muscle \\
\hline \multirow{3}{*}{$\alpha$ tocopherol (mg/g) } & ST & 2.02 & 1.34 & \multirow{3}{*}{0.14} & \multirow{3}{*}{ * } & \multirow{3}{*}{ NS } & \multirow{3}{*}{ NS } \\
\hline & SM & 1.98 & 1.49 & & & & \\
\hline & LD & 2.12 & 1.34 & & & & \\
\hline \multirow{3}{*}{ MDA (mg/kg) } & ST & 0.014 & 0.015 & \multirow{3}{*}{0.01} & \multirow{3}{*}{ NS } & \multirow{3}{*}{ NS } & \multirow{3}{*}{ NS } \\
\hline & SM & 0.018 & 0.015 & & & & \\
\hline & LD & 0.014 & 0.012 & & & & \\
\hline
\end{tabular}

NS = not significant; ${ }^{*} \mathrm{P}<0.05$.

\section{Conclusion}

Podolian meat is naturally characterised by a beneficial content of PUFA, showing a fatty acid profile with high nutritional and nutraceutical properties. In addition, animals reared at pasture with supplementation displayed an improvement in the intramuscular fatty acid profile, in terms of unsaturation, and produced meat with higher EPA and DHA content which is a very interesting result from a human health perspective. These results may represent an adequate compromise in formulating finishing diets to achieve good performance and meat quality, optimising, at the same time, feed availability. This may help to preserve and to promote this native breed, which is an important resource for eco-sustainable development of marginal areas of Southern Italy.

\section{References}

[1] Resurreccion, A.V.A. (2004) Sensory Aspects of Consumer Choices for Meat and Meat Products. Meat Science, 66, 11-20. http://dx.doi.org/10.1016/S0309-1740(03)00021-4

[2] Simopulos, A.P. (2002) The Importance of the Ratio of Omega-6/Omega-3 Essential Fatty Acids. Biomedicine and Pharmacotherapy, 56, 365-379. http://dx.doi.org/10.1016/S0753-3322(02)00253-6

[3] French, P., O’Riordan, E.G., Monahan, F.J., Caffrey, P.J., Vidal, M., Mooney, M.T., Troy, D.J. and Moloney, A.P. (2000) Meat Quality of Steers Finished on Autumn Grass, Grass Silage or Concentrate-Based Diets. Meat Science, 56, 173-180. http://dx.doi.org/10.1016/S0309-1740(00)00037-1

[4] Nurnberg, K., Dannenberger, D., Nuernberg, G., Ender, K. and Scollan, N. (2003) N-3 Fatty Acids and Conjugated Linoleic Acids of Longissimus Muscle in Different Cattle Breeds. Proceedings of 54th Annual Meeting of EAAP, Rome, 31 August-3 September 2003, 129.

[5] Yang, A., Lanari, M.C., Brewster, M. and Tume, R.K. (2002) Lipid Stability and Meat Colour of Beef from Pastureand Grain-Fed Cattle with or without Vitamin E supplement. Meat Science, 60, 41-50. http://dx.doi.org/10.1016/S0309-1740(01)00103-6

[6] Napolitano, F., Pacelli, C., De Rosa, G., Braghieri, A. and Girolami, A. (2005) Sustainability and Welfare of Podolian cattle. Livestock Production Science, 92, 323-331. http://dx.doi.org/10.1016/j.livprodsci.2004.08.012

[7] ANABIC (2013). http://www.anabic.it

[8] Braghieri, A., Pacelli, C., De Rosa, G., Girolami, A., De Palo, P. and Napoletano, F. (201) Podolian Beef Production on Pasture and in Confinement. Animal, 5, 927-937. http://dx.doi.org/10.1016/j.livprodsci.2004.08.012

[9] Jarrige, R. (1988) Alimentation des Bovins Ovins \& Caprins. Institut National de la Recherche Agronomique, Paris.

[10] AOAC (1995) Official Methods of Analysis. Association of Official Analytical Chemists. Arlington, 78, 162-166.

[11] Folch, J., Lees, M. and Stanley, S.G.H. (1957) A Simple Method for the Isolation and Purification of Total Lipids from Animal Tissues. Journal of Biological Chemistry, 226, 497-509. http://www.jbc.org/content/226/1/497.full.pdf+html

[12] Ulbricht, T.L.V. and Southgate, D.A.T. (1991) Coronary Heart Disease: Seven Dietary Factors. The Lancet, 338, 985-992. http://dx.doi:10.1016/0140-6736(91)91846-M

[13] Piironen, V., Syvaoja, E., Varo, P., Salminem, K. and Koivistoinen, P. (1985) Tocopherols and Tocotienols in Finnish Foods: Meat and Meat Products. Journal of Agricultural and Food Chemistry, 33, 1215-1218. http://dx.doi.org/10.1021/jf00066a050

[14] Salih, A.M., Smith, D.M., Price, J.F. and Dawson, L.E. (1987) Modified Extraction 2-Thiobarbituric Acid Method for Measuring Oxidation in Poultry. Poultry Science, 66, 1483-1488. http://dx.doi.org/10.3382/ps.0661483 
[15] SAS Institute (2011) SAS/STAT User’s Guide (Version 9.2). Statistical Analysis System Inst, Cary.

[16] French, P., Stanton, C., Lawless, F., O’Riordan, E.G., Monahan, F.J., Caffrey, P.J. and Moloney, A.P. (2000) Fatty Acid Composition, Including Conjugated Linoleic Acid of Intramuscular Fat From Steers Offered Grazed Grass, Grass Silage or Concentrate-Based Diets. Journal of Animal Science, 78, 2849-2855.

http://www.journalofanimalscience.org/content/78/11/2849

[17] Food Advisory Committee (1990) Report on Review of Food Labelling and Advertising. Her Majesty’s Stationery Office, London.

[18] Williamson, C.S., Foster, R.K., Stanner, S.A. and Buttriss, J.L. (2005) Red Meat in the Diet. Nutrition Bulletin, 30, 323-355. http://dx.doi.org/10.1111/j.1467-3010.2005.00525.x

[19] Jiménez-Colmenero, F., Ventanas, J. and Toldrá, F. (2010) Nutritional Composition of Dry-Cured Ham and Its Role in a Healthy Diet. Meat Science, 84, 585-593. http://dx.doi.org/10.1016/j.meatsci.2009.10.029

[20] Hu, F.B., Manson, J.E. and Willett, W.C. (2001) Types of Dietary Fat and Risk of Coronary Heart Disease: A Critical Review. Journal of American College Nutrition, 20, 5-19. http://dx.doi.org/10.1080/07315724.2001.10719008

[21] Sprecher, H. (2000) Metabolism of Highly Unsaturated n-3 and n-6 Fatty Acids. BBA Molecular and Cell Biology of Lipids, 1486, 219-231. http://dx.doi.org/10.1016/S1388-1981(00)00077-9

[22] Givens, D.I., Kliem, K.E. and Gibbs, R.A. (2006) The Role of Meat as a Source of n $\omega 3$ Polyunsaturated Fatty Acids in the Human Diet. Meat Science, 74, 209-218. http://dx.doi.org/10.1016/j.meatsci.2006.04.008

[23] Realini, C.E., Duckett, S.K, Brito, G.W., Dalla Rizza, M. and DeMattos, D. (2004) Effect of Pasture vs. Concentrate Feeding with or without Antioxidants on Carcass Characteristics, Fatty Acid Composition, and Quality of Uruguayan Beef. Meat Science, 66, 567-577. http://dx.doi.org/10.1016/S0309-1740(03)00160-8

[24] Williams, C. (2000) Dietary Fatty Acids and Human Health. Annales de Zootechnie, 49, 165-180. http://dx.doi.org/10.1051/animres:2000116

[25] Ha, Y.L., Storkson, J. and Pariza, M.W. (1990) Inhibition of Benzo[A]Pyrene-Induced Mouse Forestomach Neoplasia by Conjugated Dienoic Derivatives of Linoleic Acid. Cancer Research, 50, 1097-1101.

[26] Du, M., Anh, D.U. and Sell, J.L. (2000) Effects of Dietary Conjugated Linoleic Acid and Linoleic: Linolenic Acid Ratio on Polyunsaturated Fatty Acid Status in Laying Hens. Poultry Science, 79, 1749-1756. http://dx.doi.org/10.1093/ps/79.12.1749

[27] Department of Health (1994) Nutritional Aspects of Cardiovascular Disease. Report on Health and Social Subjects no 46, HMSO, London.

[28] Choi, N.J., Enser, M., Wood, J.D. and Scollan, N.D. (2000) Effect of Breed on the Deposition in Beef Muscle and Adipose Tissue of Dietary n-3 Polyunsaturated Fatty Acids. Animal Science, 71, 509-519.

[29] De la Fuente, J., Diaz, M.T., Alvarez, I., Oliver, M.A., Fonti Furnols, M., Sanudo, C. Campo, M.M. Montossi, F., Nute, G.R. and Caneque, V. (2009) Fatty Acid and Vitamin E Composition of Intramuscular Fat in Cattle Reared in Different Production Systems. Meat Science, 82, 331-337. http://dx.doi.org/10.1016/j.meatsci.2009.02.002

[30] Gatellier, P., Mercier, Y., Juin, H. and Renerre, M. (2005) Effect of Finishing Mode (Pasture- or Mixed-Diet) on Lipid Composition, Colour Stability and Lipid Oxidation in Meat from Charolais Cattle. Meat Science, 69, 175-186. http://dx.doi.org/10.1016/j.meatsci.2004.06.022

[31] Enser, M., Hallet, K.G., Hewett, B., Fursey, G.A., Wood, J.D. and Harrington, G. (1998) Fatty Acid Content and Composition of UK Beef and Lamb Muscle in Relation to Production System and Implications for Human Nutrition. Meat Science, 49, 329-341. http://dx.doi.org/10.1016/S0309-1740(97)00144-7

[32] O’Sullivan, A., Galvin, K., Moloney, A.P., Troy, D.J., O’Sullivan, K. and Kerry, J.P. (2003) Effect of Pre-Slaughter Rations of Forage and/or Concentrates on the Composition and Quality of Retail Packaged Beef. Meat Science, 63, 279-286. http://dx.doi.org/10.1016/S0309-1740(02)00082-7

[33] Nurnberg, K., Dannenberg, D., Nuernberg, G., Ender, K., Voigt, J., Scollan, N.D., Wood, J.D., Nute, G.R. and Richardson, R.I. (2005) Effect of Grass-Based and a Concentrates Feeding System on Meat Quality Characteristics and Fatty Acid Composition of longissimus Muscle in Different Cattle Breeds. Livestock Production Science, 94, 137-147. http://dx.doi.org/10.1016/j.livprodsci.2004.11.036

[34] Faustman, C., Cassens, R.G., Schaefer, D.M., Buege, D., Williams, S.N. and Scheller, K.K. (1989) Improvement of Pigment and Lipid Stability in Holstein Steer Beef by Dietary Supplementation with Vitamin E. Journal of Food Science, 54, 858-862. http://dx.doi.org/10.1111/j.1365-2621.1989.tb07899.x

[35] Morrissey, P.A., Buckley, D.J., Sheehy, P.J.A. and Monahan, F.J. (1994) Vitamin E and Meat Quality. Proceeding of the Nutrition Society, 53, 289-295.

[36] Gray, J.I. (1978) Measurement of Lipid Oxidation: A Review. Journal of the American Oil Chemists Society, 55, 539546. http://dx.doi.org/10.1007/BF02668066 